\title{
Powłoki poliuretanowe (PUR) nakładane na armaturę gazową przeznaczoną do stosowania w ziemi
}

\begin{abstract}
Artykuł przedstawia problematykę związaną z nakładaniem i badaniem powłok poliuretanowych nałożonych na armaturę stalową (w odniesieniu do zasuw i zaworów) przeznaczoną do instalowania w ziemi. Z uwagi na wątpliwości co do zasadności stosowania metod badawczych opisanych w dostępnych specyfikacjach wykonywania tych badań na próbkach w postaci rur i kształtek rurowych - postanowiono przeprowadzić badania doświadczalne powłoki nałożonej na armaturze, stosując metody badawcze opisane w normie PN-EN 10290:2005 [7], która określa wymagania i badania dla powłok PUR nakładanych na rury i łączniki. W artykule zwrócono uwagę na najczęstsze przyczyny powstawania złych jakości powłok oraz przedstawiono wyniki badań ich wybranych właściwości.
\end{abstract}

Słowa kluczowe: zawór, powłoki na zaworach, powłoka, poliuretanowe, PUR.

\section{Polyurethane Coatings (PUR) applied on gas valves designed for use in the ground}

This article presents problems related to the application and testing of polyurethane coatings applied to steel fittings (for valves) intended for installation in the ground. In view of the doubts as to the applicability of the test methods described in the available specifications, to perform these tests on tubes and pipe fittings, it was decided to carry out experimental tests of the coating applied on the fittings, using the test methods described in EN 10290: 2005 [7], which specifies requirements and tests for PUR coatings applied to pipes and fittings. The most common causes of poor quality coatings were presented in the article.

Key words: valves, coatings on valves, coating, polyurethane, PUR.

\section{Rodzaje powłok ochronnych stosowanych na armaturze stalowej do sieci gazowych}

W zależności od miejsca instalacji armaturę gazową do sieci można podzielić na instalowaną na zewnątrz oraz instalowaną w gruncie. Armatura instalowana na zewnątrz narażona jest na wpływ zróżnicowanych warunków atmosferycznych - na niskie, wysokie temperatury, opady deszczu oraz działanie promieni UV. Armatura przeznaczona do instalacji w gruncie narażona jest na oddziaływanie elektrolitu glebowego, o właściwościach agresywnych, na dużą wilgotność oraz mikroorganizmy. Dodatkowo armatura instalowana w ziemi powinna być przystosowana do współpracy z ochroną katodową.

Ze względu na miejsce instalacji armaturę pokrywa się odpowiednimi powłokami ochronnymi. Armatura przeznaczona do instalowania w ziemi najczęściej pokrywana jest powłokami epoksydowymi FBE lub powłokami poliuretanowymi PUR. Powłoki te powinny charakteryzować się wysoką przyczepnością do stali, elastycznością, odpornością na środowi- sko glebowe, często agresywne, oraz wysoką odpornością na uszkodzenia mechaniczne. Ponadto powinny współpracować $\mathrm{z}$ ochroną katodową.

\section{Powtoki epoksydowe FBE}

Powłoki epoksydowe to powłoki, w których zastosowano związki epoksydowe. Najczęściej jest to mieszanina z żywicy epoksydowej, usieciowionej z rdzeniem wstecznym lub utwardzaczem. Powłoki te częściowo wyparły powłoki proszkowe, ponieważ po ich nałożeniu nie ma konieczności wygrzewania elementu w celu ich utwardzenia. Są odporne na zarysowania, charakteryzują się wysoką twardością i przyczepnością. Są przystosowane do współpracy z ochroną katodową. Często wykorzystuje się je również jako pierwszą warstwę w powłokach fabrycznych trójwarstwowych PE lub PP. Niektórzy producenci stosują je także jako pierwszą warstwę pod powłokę poliuretanową. 


\section{Powtoki poliuretanowe PUR}

W Polsce armatura do sieci gazowych instalowana w ziemi pokrywana jest najczęściej powłokami poliuretanowymi typu PUR. Są to powłoki dwuskładnikowe, nakładane w stanie ciekłym i utwardzane bez podgrzewania. Charakteryzują się wysoką odpornością na warunki atmosferyczne, dobrą przyczepnością i odpornością na uszkodzenia mechaniczne. Więcej informacji związanych z powłokami poliuretanowymi i ich nakładaniem można znaleźć w innych opracowaniach [2, 3]. Powłoki poliuretanowe mogą być stosowane na armaturach instalowanych na zewnątrz, jednak muszą być dodatkowo odporne na promieniowanie UV. Powłoki te przystosowane są do współpracy z ochroną katodową. W podwyższonych temperaturach, powyżej $100^{\circ} \mathrm{C}$, tracą swoje niektóre właściwości, między innymi przyczepność. Przy używaniu tych powłok szczególną uwagę należy zwrócić na warunki, w jakich są nakładane, oraz na stan powierzchni stali, jej oczyszczenie, niską wilgotność i odpowiednią temperaturę. Wymiary armatury oraz jej kształt utrudniają często poprawne nałożenie powłoki. Najbardziej newralgicznymi miejscami są śruby, przewody sterownicze, przewody pomocnicze, rurki impulsowe, zagięcia itp. (fotografia 1). Miejsca te szczególnie trudno pokryć warstwą powłoki w sposób zapewniający jednorodną grubość i szczelność powłoki. Obszary te również mogą być narażone na pękanie i odspajanie. Słaba przyczepność powłok i ich grubość mogą mieć negatywny wpływ na jednostkową rezystancję przejścia powłoki, co jest kluczowym parametrem w przypadku powłok ochronnych stosowanych w ziemi.

\section{Powtoki malarskie}

Powłoki malarskie to najczęściej termoutwardzalne farby proszkowe, odporne na promieniowanie UV, o dobrej przyczepności i elastyczności, nanoszone w cienkich warstwach. Barwa dobierana jest $\mathrm{w}$ zależności od zapotrzebowania. Zewnętrzną armaturę poddaje się często ponownemu malowaniu farbami tradycyjnymi, odpornymi również na promieniowanie UV.

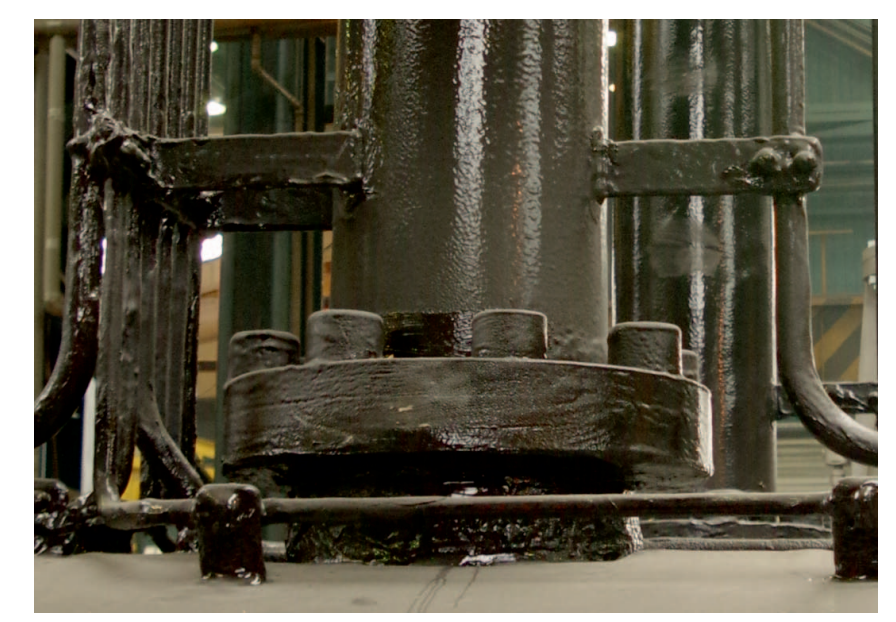

Fot. 1. Wrażliwe elementy armatury (fot. T. Minor)

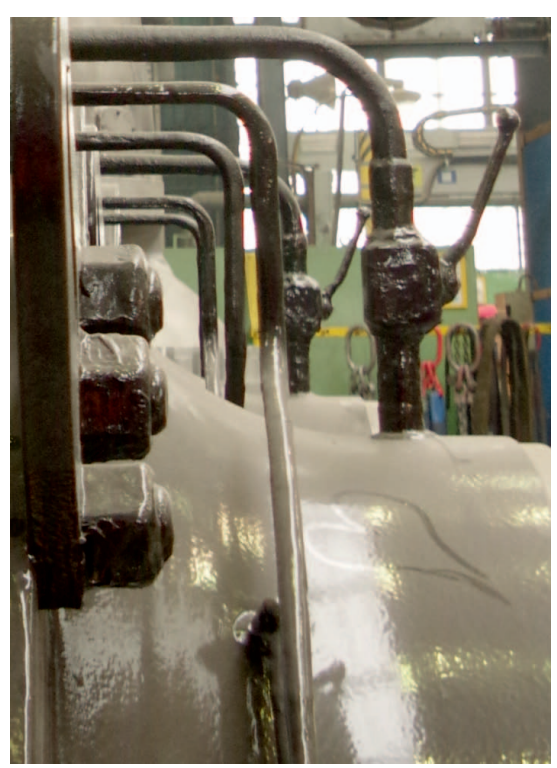

\section{Specyfikacja dotycząca armatury stalowej pokrytej powłoką poliuretanową}

Powłoki poliuretanowe są najczęściej nakładane na armaturę stalową (zawory, zasuwy), kształtki, łączniki i rury przeznaczone do instalacji w ziemi. W zależności od rodzaju wyrobu, na jaki ma być nałożona powłoka, powinno stosować się odpowiednie specyfikacje i normy w celu zbadania właściwości powłoki przeznaczonej do określonego wykorzystania. Dostępne są dwie specyfikacje: europejska, uznana w Polsce, norma PN-EN 10290:2005 [7] oraz niemiecka norma DIN 30677-2:1988 [6].

\section{PN-EN 10290:2005}

Norma PN-EN 10290:2005 Rury stalowe i łaczniki na rurociagi przybrzeżne i morskie. Powtoki zewnętrzne z poliuretanu lub poliuretanu modyfikowanego nanoszone $w$ stanie ciekłym [7] określa wymagania dla powłok nakładanych na rury stalowe i łączniki stosowane na rurociągach w wodzie mor- skiej i ziemi. Badania dla oceny typu wykonywane są na rurach i fragmentach rur, a nie na armaturze. $O$ ile nałożenie równomiernej powłoki na rurach jest możliwe, o tyle na armaturze sprawia to bardzo dużą trudność i wymaga dużego doświadczenia. Nasuwa się więc pytanie, czy zasadne jest wykonywanie badań na rurach i stalowych kształtkach rurowych w ocenie powłok stosowanych na armaturze.

\section{DIN 30677:1988}

Norma niemiecka DIN 30677-2:1988 Zewnętrzne zabezpieczenie antykorozyjne armatur uktadanych $w$ ziemi. Powlekanie duroplastami dla podwyższonych wymagań [6] dotyczy zabezpieczeń antykorozyjnych armatur układanych w ziemi. Obejmuje ona powłoki EP - epoksydy, PUR - poliuretany, PUR-Teer - smołę poliuretanową. Zakresem badań jest bardzo zbliżona do normy PN-EN 10290:2005, lecz nie zawiera 
wszystkich metod badawczych. Wymagania co do właściwości powłoki również w niektórych przypadkach są inne.

\section{Krajowa ocena techniczna}

Zgodnie z aktualnymi przepisami ustawy z dnia 16 kwietnia 2004 r. o wyrobach budowlanych [10] (art. 5 pkt 2): $W y$ rób budowlany nieobjęty norma zharmonizowana, dla której zakończyt się okres koegzystencji, o którym mowa $w$ art. 17 ust. 5 rozporządzenia $\mathrm{Nr}$ 305/2011, i dla którego nie zostata wydana europejska ocena techniczna, może być wprowadzony do obrotu lub udostepniany na rynku krajowym, jeżeli został oznakowany znakiem budowlanym, którego wzór określa załacznik nr 1 do ustawy. Art. 8 pkt 1 przewiduje, że: Oznakowanie znakiem budowlanym umieszcza się na wyrobie budowlanym, dla którego producent sporzadzit, na swoja wyłaczna odpowiedzialność, krajowa deklarację właściwości użytkowych wyrobu budowlanego, zwana dalej „,krajowa deklaracja”. Właściwości użytkowe wyrobu budowlanego, zadeklarowane w krajowej deklaracji zgodnie z właściwa przedmiotowo Polska Norma wyrobu lub krajowa ocena techniczna, należy odnieść do tych zasadniczych charakterystyk, które maja wptyw na spetnienie podstawowych wymagań przez obiekty budowlane, zgodnie z zamierzonym zastosowaniem tego wyrobu. Informacje o właściwościach użytkowych wyrobu budowlanego w odniesieniu do zasadniczych charakterystyk tego wyrobu można podać wytacznie, o ile zostaty określone $w$ krajowej deklaracji. Zgodnie z art. 9 pkt 1 tej ustawy [10] krajową ocenę techniczną wydaje się dla wyrobu budowlanego:
- nieobjętego zakresem przedmiotowym Polskiej Normy wyrobu albo

- jeżeli w odniesieniu do co najmniej jednej zasadniczej charakterystyki wyrobu budowlanego metoda oceny przewidziana w Polskiej Normie wyrobu nie jest właściwa, albo - jeżeli Polska Norma wyrobu nie przewiduje metody oceny w odniesieniu do co najmniej jednej zasadniczej charakterystyki wyrobu budowlanego.

Wzór krajowej oceny technicznej określony jest w rozporządzeniu [8].

Wyroby, dla jakich można wydać krajową ocenę techniczną, określa załącznik nr 1 (tablica) do rozporządzenia Ministra Infrastruktury i Budownictwa z dnia 17 listopada 2016 r. w sprawie sposobu deklarowania właściwości użytkowych wyrobów budowlanych oraz sposobu znakowania ich znakiem budowlanym (Dz.U. z 2016 r., poz. 1966) [9].

Powłoki stosowane na armaturze wraz z armaturą określa pozycja 28 tablicy ze wskazanego załącznika nr 1, w której zapisano: Wyroby do transportu/dystrybucji/magazynowania gazu i paliwa plynnego przeznaczonego do zasilania systemów ogrzewania/chłodzenia w budynkach, z zewnętrznego zbiornika magazynowego lub od końcowej stacji redukcji ciśnienia sieci do wlotu do urządzeń do ogrzewania/chłodzenia w budynku: zestawy rurowe, rury, ksztattki, zbiorniki, systemy alarmowania o wyciekach i urzadzenia zapobiegajace przepetnieniu, elementy złączne, spoiwa, złacza, uszczelnienia złaczy, uszczelki, kanaty i przewody zabezpieczajace, podparcia rur/przewodów, armatura regulacyjna i odcinajaca, wyposażenie pomocnicze zabezpieczajace [9].

\section{Przygotowanie powierzchni}

Najważniejszą czynnością przed nałożeniem powłoki jest prawidłowe przygotowanie powierzchni oraz kontrola warunków środowiskowych na powierzchni stali i w obrębie miejsca nakładania powłoki.

Powierzchnia stali przed nałożeniem powłoki powinna być czysta, sucha i oczyszczona przez śrutowanie. Na fotografii 2

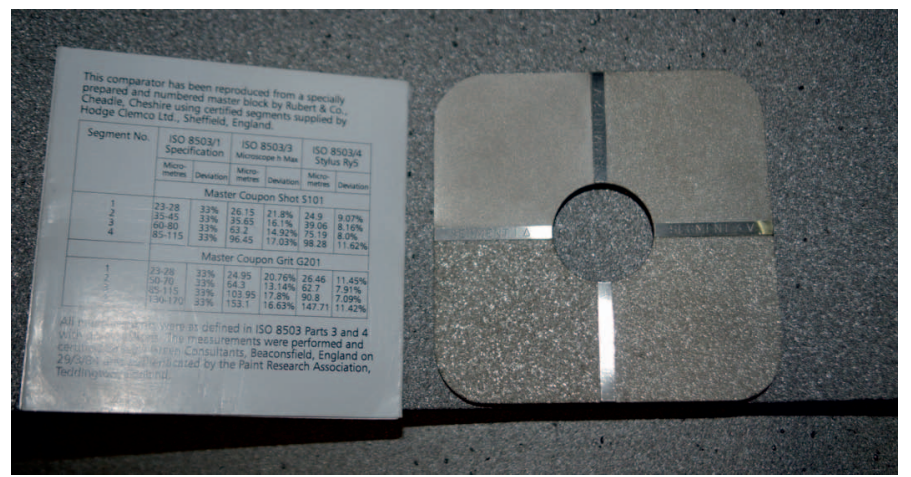

Fot. 2. Sprawdzenie przygotowania powierzchni (fot. T. Minor) widzimy sposób sprawdzenia poprawności przygotowania powierzchni przed nałożeniem powłoki.

Fotografia 3 przedstawia sprawdzenie warunków otoczenia przed nałożeniem powłoki. Najważniejsze parametry to: temperatura punktu rosy, temperatura otoczenia, temperatura powierzchni przygotowanej powłoki oraz wilgotność.

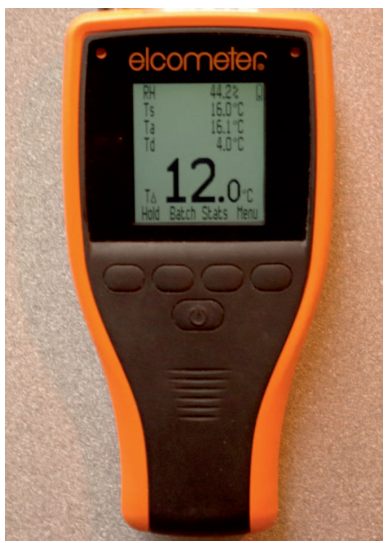

Fot. 3. Sprawdzenie warunków otoczenia przy powierzchni stali (fot. T. Minor) 


\section{Wybrane badania}

Badania powłoki na armaturze (zasuwach) zostały wykonane według metod opisanych w normie PN-EN 10290:2005 [7].

\section{Wygląd i ciaglość powtok}

Pierwszym badaniem była ocena wizualna stanu powierzchni powłok nałożonych na armaturze. Oceniana powłoka powinna być jednolitej barwy, gładka, nie powinna posiadać nierówności, pęcherzy i zadrapań. Wynik badania nie był satysfakcjonujący, powłoka została nałożona w sposób nieprawidłowy, miała zacieki, pory i nierówności (fotografia 4). Zacieki w dolnej części armatury spowodowane zostały najpewniej zbyt szybkim nakładaniem lub zbyt grubą pierwszą warstwą powłoki.

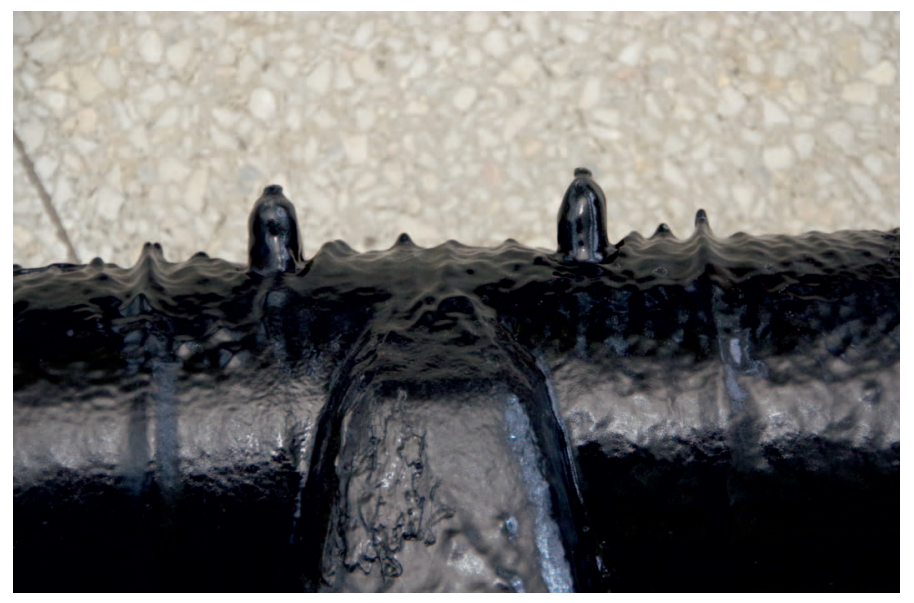

Fot. 4. Stan powierzchni badanej próbki (fot. T. Minor)

\section{Grubość suchej warstwy powłoki}

Pomiar grubości powłoki według normy PN-EN 10290:2005 należy wykonać na rurze w osi po 3 pomiary co $90^{\circ}$. W przypadku armatury badanie polegało na wykonaniu 12 pomiarów dla każdej próbki. Wynikiem jest średnia arytmetyczna wszystkich pomiarów. Norma ta rozróżnia również dwie klasy grubości powłoki - pierwszą o grubości minimum $1000 \mu \mathrm{m}$ oraz drugą o grubości minimum $1500 \mu \mathrm{m}$. Dopuszczone jest również nakładanie powłok o większej grubości, na zlecenie zamawiającego.

Badania przeprowadzone na armaturze obejmowały odcinki rurowe, powierzchnie płaskie, krawędzie zewnętrzne oraz inne powierzchnie umożliwiające poprawne wykonanie pomiaru.

Wyniki otrzymane dla próbek o nominalnej grubości powłoki do $3 \mathrm{~mm}$ wraz z niepewnością pomiaru uzyskały wynik pozytywny. Próbki o nominalnej grubości do $4 \mathrm{~mm}$ wraz z niepewnością pomiarową nieznacznie przekroczyły wymaganą wartość. Na podstawie badań grubości widać, że nałożenie jednolitej warstwy powłoki na armaturze jest bardzo trudne. Na zewnętrznych krawędziach grubość powłoki może być cieńsza, a w wewnętrznych załamaniach lub u dołu armatury grubsza, z uwagi na ściekanie powłoki podczas nakładania. Nałożona powłoka na badanych wyrobach miała grubość niejednorodną.

\section{Wykrywanie nieciaglości (badanie szczelności powłoki)}

Badanie to polega na wykrywaniu nieciągłości (nieszczelności, braku porów) powłoki izolacyjnej. Podczas sprawdzania szczelności powłoki izolacyjnej za pomocą poroskopu wykorzystującego napięcie stałe - zgodnie z normą PN-EN 10290:2005 napięcie probiercze powinno wynieść $8 \mathrm{~V} / \mu \mathrm{m}$, jednak nie więcej niż $20 \mathrm{kV}$. Wynik badania był negatywny, na każdej z próbek wykryto około 3 $\div 6$ defektów (nieszczelności), głównie w rejonie śrub korpusu oraz na wewnętrznych załamaniach powierzchni (fotografia 5). Defekty w powłoce izolacyjnej mogą powstać na skutek zbyt szybkiego nakładania jednej grubej warstwy powłoki lub złych warunków otoczenia, tj. zbyt dużej wilgotności. Zgodnie z normą miejsca te zostały naprawione i badanie zostało wykonane ponownie. Po naprawie wynik badania był pozytywny.

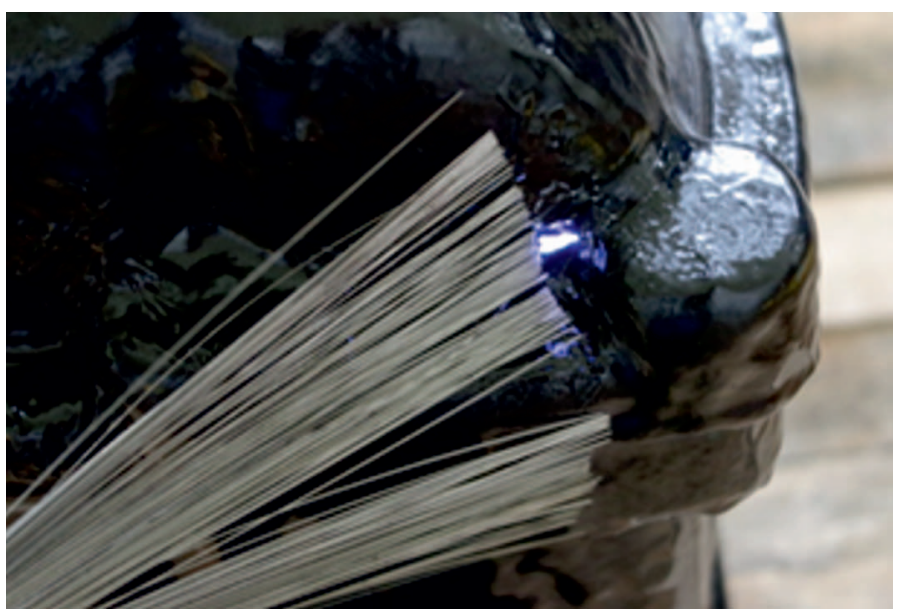

Fot. 5. Przebicie izolacji PUR na skutek przyłożonego napięcia próbnego (fot. T. Minor)

\section{Badanie przylegania powtok}

Ważną właściwością powłoki PUR jest jej przyleganie do stali. Badanie przylegania pozwoliło określić przyczepność powłoki do powierzchni stalowej. Z uwagi na to, że powłoki te są nakładane bezpośrednio na stal, przygotowanie powierzchni przed jej nałożeniem jest bardzo ważne.

\section{Sprawdzenie utraty przyczepności (tzw. metoda X)}

Badanie to polega na sprawdzeniu przylegania powłoki do stali poprzez podważenie powłoki w miejscu nacięcia - nacięcie to wykonywane jest pod kątem $30^{\circ}$. W miejscu skrzyżowania nacięć podważa się powłokę i mierzy utratę przyczepności do stali. Uzyskany wynik badania był negatywny. 


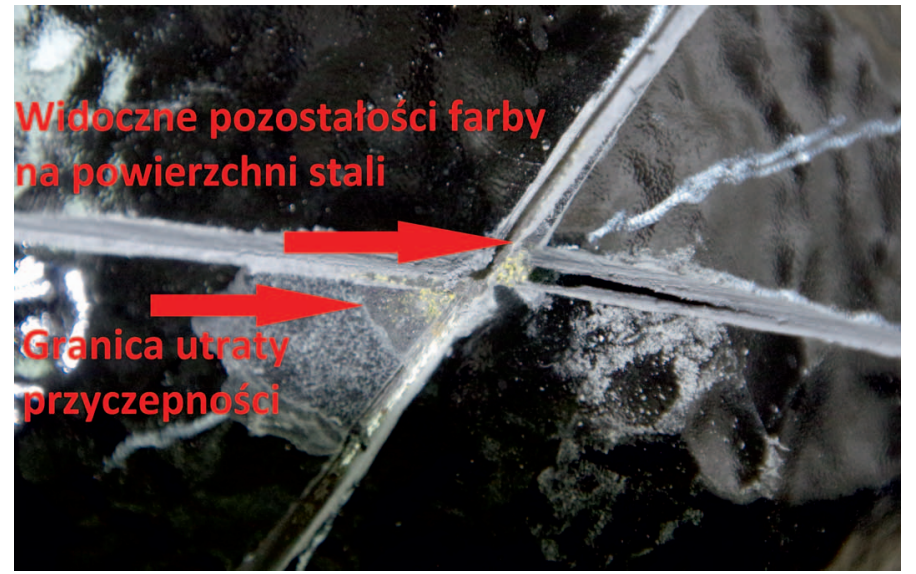

Fot. 6. Brak przylegania w miejscu nacięcia (fot. T. Minor)

Na fotografii 6 możemy zauważyć granicę utraty przyczepności do stali oraz źle przygotowaną powierzchnię stalową przed nałożeniem powłoki. Fotografia 7 pokazuje rozwarstwienie powłoki.

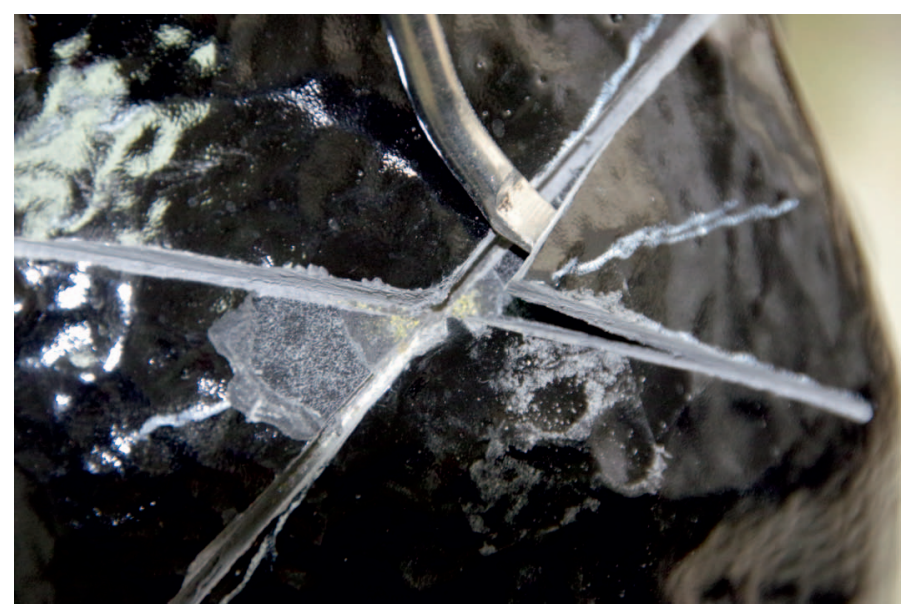

Fot. 7. Rozwarstwienie w warstwie (fot. T. Minor)

\section{Metoda odciagania stemplem}

Badanie polega na sprawdzeniu przylegania powłoki do stali metodą odciągania stemplem. Próbę wykonuje się przy użyciu maszyny wytrzymałościowej. Pomiar siły przylegania wyliczony jest przez oprogramowanie podczas wykonywania pomiaru siły z uwzględnieniem powierzchni stempla. Wokół stempla wykonuje się nacięcia, aby badana powierzchnia powłoki odpowiadała powierzchni stempla. Na fotografiach 8 i 9 można zobaczyć jednorodne oderwanie powłoki w warstwie, co wskazuje na niewłaściwe nałożenie powłoki. Wynik badania uznano za negatywny z uwagi na rozwarstwianie się powłoki i nieuzyskanie wymaganej siły jej przyczepności.

Wykonane badania pokazały wadliwe nałożenie powłoki. Podczas badania przylegania metodą odrywania stemplem powłoka uległa rozwarstwieniu w warstwie w sposób jednorodny, co świadczy o niewłaściwym procesie nakładania powłoki. Badania metodą utraty przyczepności (tzw. X) dodatkowo ujawniły wady przygotowania podłoża, których skutkiem

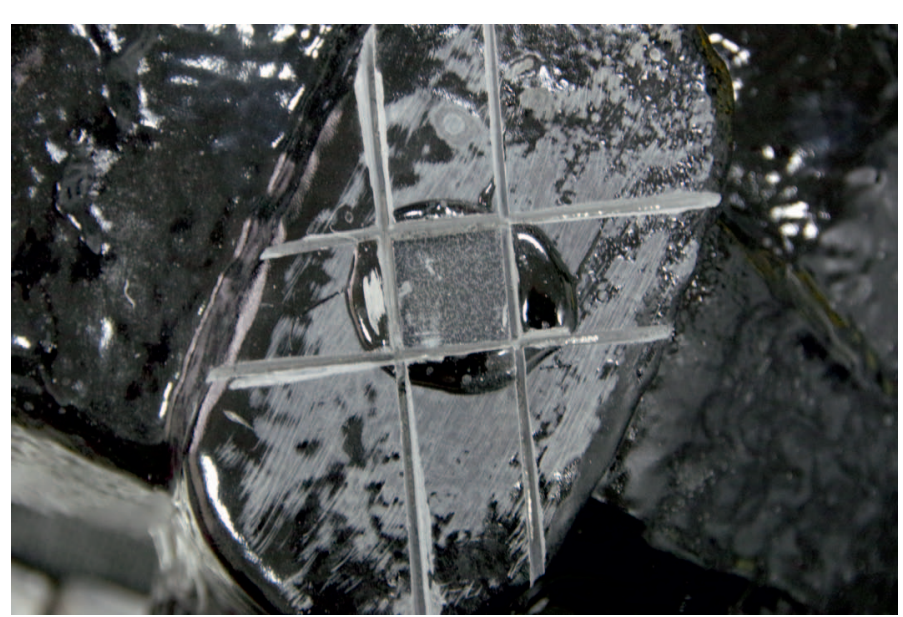

Fot. 8. Powierzchnia próbki, rozwarstwienie w warstwie (fot. T. Minor)

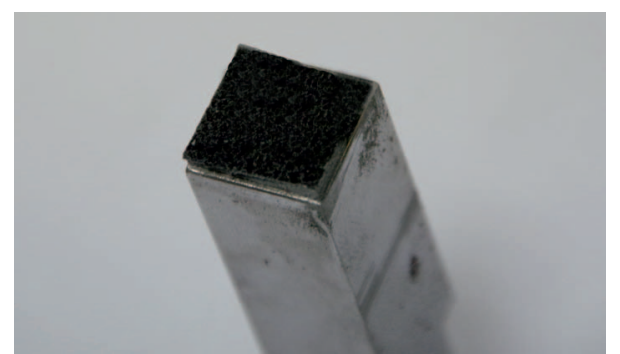

Fot. 9. Powierzchnia stempla, rozwarstwienie w warstwie (fot. T. Minor)

było oderwanie się powłoki od stali. Powodem rozwarstwienia w warstwie mogły być zbyt długie odstępy w czasie pomiędzy nakładaniem kolejnych warstw lub to, że podczas schnięcia pierwszej warstwy mogło nastąpić zawilgocenie powierzchni lub jej zanieczyszczenie.

\section{Odspajanie katodowe}

Badanie to ma na celu sprawdzenie wielkości odspajania katodowego, czyli odrywania się powłoki od stali pod wpływem przepływu prądu katodowej polaryzacji stali. Armatura współpracująca z sieciami gazowymi musi być przystosowana do współpracy z systemami ochrony katodowej.

Negatywny wynik podczas badania odspajania katodowego, przedstawiony w tablicy 1 i na fotografiach 10, 11 i 12 , nie jest niczym zaskakującym w związku z negatywnym wynikiem w badaniu przyczepności do stali. Odspajanie katodowe występuje podczas polaryzacji stali (armatury) zainstalowanej w ziemi w miejscach powstałych defektów w izolacji. Pod wpływem przepływu prądu polaryzacji powłoka w miejscu defektu ma tendencje do odrywania (odspajania). Im gorsza przyczepność powłoki do stali, tym odspajanie jest bardziej prawdopodobne i ma większą skalę.

Problem odspajania katodowego i jego wpływu na jakość obiektu opisany jest w artykule pt.: Odspojenie katodowe powłoki jako zjawisko mogące naruszyć integralność gazociagu [1, 4]. 


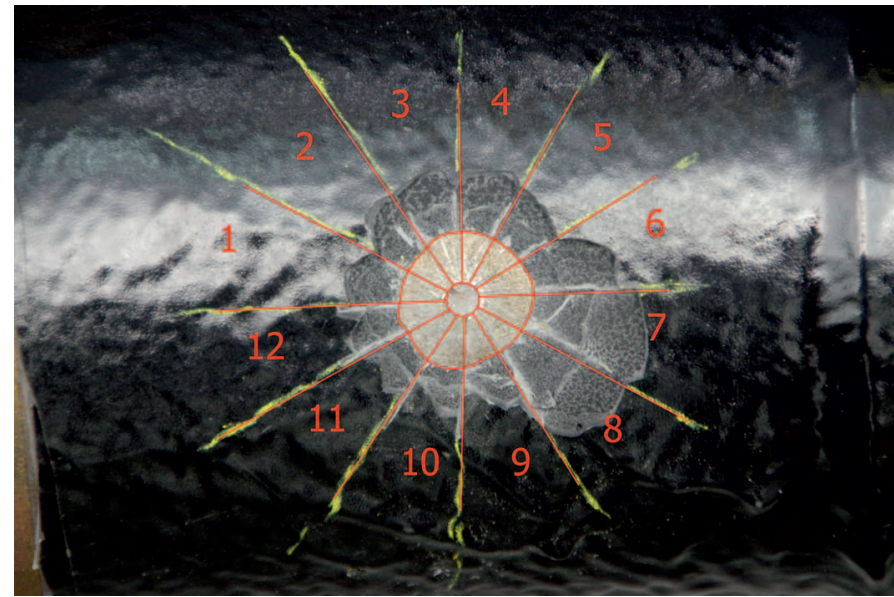

Fot. 10. Wynik odspajania katodowego po 28 dniach w temperaturze $23 \pm 2^{\circ} \mathrm{C}$

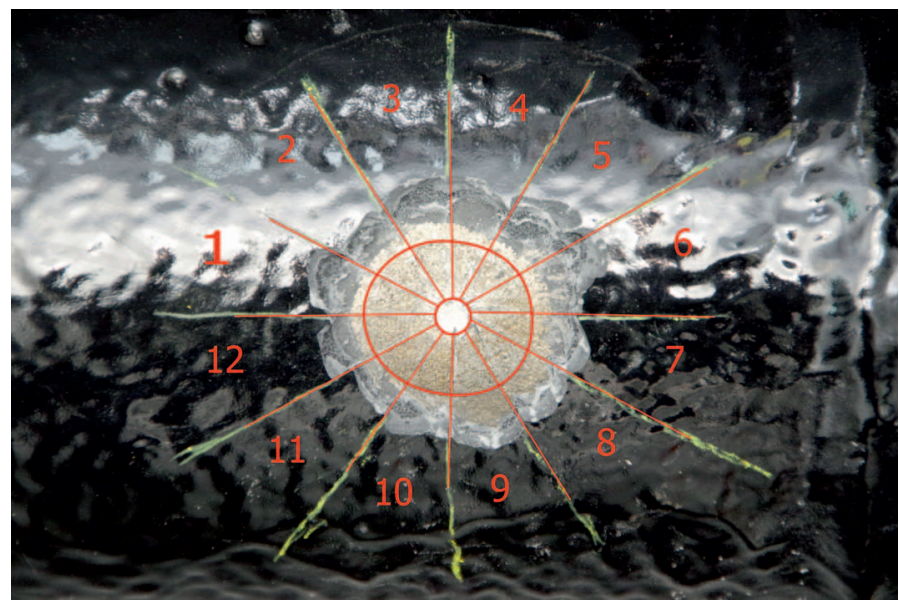

Fot. 11. Wynik odspajania katodowego po 48 godzinach w temperaturze $60 \pm 2^{\circ} \mathrm{C}$

Tablica 1. Wyniki badań odspajania katodowego

\begin{tabular}{|c|c|c|c|c|}
\hline $\begin{array}{l}\mathrm{Nr} \\
\text { próbki }\end{array}$ & $\begin{array}{c}\text { Temperatura } \\
\text { badania } \\
{\left[{ }^{\circ} \mathrm{C}\right]}\end{array}$ & $\begin{array}{c}\text { Średni promień zaniku } \\
\text { przyczepności } x_{s} \\
\text { Odchylenie standardowe } s\left(x_{s}\right) \\
\text { Niepewność rozszerzona } \\
\text { dla } k=2 \text { i } \alpha=0,95 \\
{[\mathrm{~mm}]}\end{array}$ & $\begin{array}{l}\text { Dopuszczalny } \\
\text { promień zaniku } \\
\text { przyczepności } \\
{[\mathrm{mm}]}\end{array}$ & $\begin{array}{c}\text { Zgodność } \\
\text { z wymaganiem }\end{array}$ \\
\hline $\mathrm{X} 1$ & $23 \pm 2$ & $\begin{array}{c}x_{s(12)}=8,77 \\
s\left(x_{s}\right)=0,34 \\
x_{\mathrm{o}}=8,77 \pm 0,20 \\
\max =9,62\end{array}$ & $\begin{array}{l}\text { średni } \\
\leq 8\end{array}$ & brak zgodności \\
\hline $\mathrm{X} 2$ & $23 \pm 2$ & $\begin{array}{c}x_{s(12)}=8,96 \\
s\left(x_{s}\right)=0,21 \\
x_{\mathrm{o}}=8,96 \pm 0,12 \\
\max =9,32\end{array}$ & $\begin{array}{l}\text { średni } \\
\leq 8\end{array}$ & brak zgodności \\
\hline $\mathrm{X} 1$ & $60 \pm 2$ & $\begin{array}{c}x_{s(12)}=12,01 \\
s\left(x_{s}\right)=0,57 \\
x_{\mathrm{o}}=12,01 \pm 0,33 \\
\max =13,65\end{array}$ & $\begin{array}{c}\text { maksymalny } \\
\leq 10\end{array}$ & brak zgodności \\
\hline $\mathrm{X} 2$ & $60 \pm 2$ & $\begin{array}{c}x_{s(12)}=13,03 \\
s\left(x_{s}\right)=0,13 \\
x_{\mathrm{o}}=13,03 \pm 0,08 \\
\max =13,56\end{array}$ & $\begin{array}{c}\text { maksymalny } \\
\leq 10\end{array}$ & brak zgodności \\
\hline
\end{tabular}
wyżej $4 \mathrm{~mm}$ ), tym gorszej może być jakości.

Badanie polega na zanurzeniu próbki w elektrolicie o ustalonym stężeniu i przetrzymywaniu jej w tych warunkach przez okres 100 dni. Minimalna oporność właściwa jest określona w zależności od klasy grubości powłoki.

Oporność właściwą obliczamy ze wzoru:

$$
R s=\frac{U S}{I}[6]
$$

gdzie:

$R s$ - oporność właściwa $\left[\Omega \cdot \mathrm{m}^{2}\right]$,

$U$ - napięcie badania [V],

$S$-powierzchnia powłoki badanej $\left[\mathrm{m}^{2}\right]$,

I - zmierzony prąd [A].

Uzyskany wynik badania był negatywny z uwagi na zbyt niską oporność właściwą powłoki (tablica 2).

Tak niska oporność właściwa powłoki może świadczyć o obecności w niej mikroporów, które w długim czasie eksploatacji powłoki zakopanej w ziemi mogą przekształcić się w większe 
Tablica 2. Wyniki badań oporności właściwej

\begin{tabular}{|c|c|c|c|c|c|c|}
\hline \multirow{2}{*}{ Nr próbki } & $\begin{array}{c}\text { Wymagania } R s_{100} \\
{\left[\Omega \mathrm{m}^{2}\right]}\end{array}$ & $\begin{array}{c}R s_{100} \\
{\left[\Omega \mathrm{m}^{2}\right]}\end{array}$ & $\begin{array}{c}R s_{70} \\
{\left[\Omega \mathrm{m}^{2}\right]}\end{array}$ & $\begin{array}{c}\text { Wymaganie } \\
R s_{100} / R s_{70}\end{array}$ & $R s_{100} / R s_{70}$ & $\begin{array}{c}\text { Zgodność } \\
\mathrm{Z} \text { wymaganiem }\end{array}$ \\
\cline { 1 - 1 } $\mathrm{X}$ X3 & \multirow{2}{*}{$\min 10^{7}$} & $5,8 \cdot 10^{4}$ & $6,1 \cdot 10^{4}$ & \multirow{2}{*}{$\geq 0,8$} & 0,95 & brak zgodności \\
\cline { 1 - 1 } & & $5,8 \cdot 10^{4}$ & $6,2 \cdot 10^{4}$ & & 0,93 & brak zgodności \\
\hline
\end{tabular}

defekty. Bardzo małe defekty powstałe w powłoce izolacyjnej są szczególnie groźne z uwagi na zagrożenia korozyjne pochodzące od prądów błądzących, co szerzej opisano w odrębnym opracowaniu [5].

Pozostałe badania wykonane według metod opisanych w normie PN-EN 10290:2005, tj. odporności na uderzenie, odporności powłoki na wgniatanie, twardość Shore’a D, zakończyły się wynikiem pozytywnym.
Przeprowadzenie badania elastyczności na próbkach w postaci armatury według normy PN-EN 10290:2005 lub DIN 30677-2:1988 nie jest możliwe. Obie normy wskazują, by wykonać to badanie na powłoce nałożonej na płytce stalowej lub na fragmencie z wyciętej rury.

Wydłużenie jest badaniem przeprowadzanym tylko na płacie powłoki o grubości ustalonej przez zamawiającego, nałożonym na folię w celu przygotowania próbek do badań.

\section{Podsumowanie}

Pomimo zaleceń, aby nałożona powłoka na armaturę była wysokiej jakości, wyniki wielu badań były niestety negatywne. Należy zwrócić uwagę, że badane wyroby pochodziły od jednego producenta i nie można jednoznacznie stwierdzić, że problem z jakością powłok PUR nakładanych na armaturę jest powszechny. Na podstawie uzyskanych wyników badań widać także, że nie każdy wyrób wprowadzony na rynek jest zgodny z wymaganiami określonymi w specyfikacjach. Zaobserwowano również, że nałożenie jednoli- tej, gładkiej, bez zacieków powłoki na armaturę jest niewątpliwie trudniejsze niż na rury stalowe czy kształtki. Badania pokazują, że próbkami do badań do oceny powłok PUR przeznaczonych do nakładania na armaturę (zasuwy, zawory) mogłyby być próbki w postaci armatury z nałożoną powłoką PUR. Niestety z uwagi na duże gabaryty, niejednorodny kształt oraz wysokie koszty armatury pokrytej powłoką tylko część metod opisanych w normie PN-EN 10290:2005 miałaby zastosowanie.

Prosimy cytować jako: Nafta-Gaz 2018, nr 3, s. 226-232, DOI: 10.18668/NG.2018.03.06

Artykuł nadesłano do Redakcji 24.11.2017 r. Zatwierdzono do druku 5.02.2018 r.

Artykuł powstał na podstawie pracy statutowej pt.: Analiza zasadności stosowania metod badawczych powłok poliuretanowych na rurociagach $w$ badaniach powtok stosowanych na armaturze stalowej uktadanej $w$ ziemi - praca INiG - PIB na zlecenie MNiSW; nr zlecenia: 0075/GP/17, nr archiwalny: DK-4100-62/17.

\section{Literatura}

[1] Pieniążek W.: Odspajanie katodowe jako wskaźnik oceny wspótpracy powłoki z ochrona katodowa - wybrane zagadnienia. XIII Krajowa Konferencja „Pomiary korozyjne w ochronie elektrochemicznej”, Ostróda 9-11.06.2014.

[2] Pieniążek W.: Powłoki przeciwkorozyjne nakładane $w$ stanie ciektym na rurociagi. Część I: Powłoki epoksydowe. Ochrona przed Korozją 2005, nr 3, s. 64-66.

[3] Pieniążek W.: Powtoki przeciwkorozyjne nakładane $w$ stanie cieklym na rurociagi. Część II: Powłoki poliuretanowe (PU). Ochrona przed Korozją 2006, nr 2, s. 42-45.

[4] Stochaj P.: Odspojenie katodowe powłoki jako zjawisko mogace naruszyć integralność gazociąu. Nafta-Gaz 2017, nr 6, s. 405-410, DOI: 10.18668/NG.2017.06.05.

[5] Stochaj P.: Prądy błądzące jako źródło zagrożenia korozyjnego gazociagów stalowych. Nafta-Gaz 2013, nr 9, s. 683-689.

\section{Akty prawne i normatywne}

[6] DIN 30677-2:1988 External corrosion protection of buried valves; heavy-duty thermoset plastics coatings.

[7] PN-EN 10290:2005 Rury stalowe i łaczniki na rurociagi przy- brzeżne i morskie. Powłoki zewnętrzne z poliuretanu lub poliuretanu modyfikowanego nanoszone w stanie ciektym.

[8] Rozporządzenie Ministra Infrastruktury i Budownictwa w sprawie krajowych ocen technicznych z dnia 17 listopada $2016 \mathrm{r}$. (Dz.U. z 2016 r., poz. 1968).

[9] Rozporządzenie Ministra Infrastruktury i Budownictwa z dnia 17 listopada 2016 r. w sprawie sposobu deklarowania właściwości użytkowych wyrobów budowlanych oraz sposobu znakowania ich znakiem budowlanym (Dz.U. z 2016 r., poz. 1966).

[10] Ustawa z dnia 16 kwietnia 2004 r. o wyrobach budowlanych (tekst jednolity z dnia 8 września 2016 r., Dz.U. z 2016 r., poz. 1570).

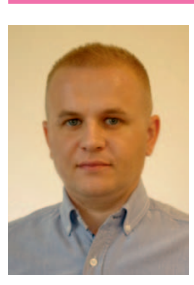

Mgr inż. Tomasz MINOR

Główny specjalista inżynieryjno-techniczny w Zakładzie Przesyłania i Dystrybucji Gazu; Kierownik Laboratorium Badań Armatury i Technik Eksploatacji Gazociągów Instytut Nafty i Gazu - Państwowy Instytut Badawczy ul. Lubicz 25 A, 31-503 Kraków E-mail: tomasz.minor@inig.pl 